\title{
IDENTIFIKASI DAN UJI PENGENDALIAN HAMA DAUN JABON SECARA INVITRO
}

\author{
Ujang W. Darmawan ${ }^{1)^{*}}$, dan Agus Ismanto ${ }^{2)}$ \\ ${ }^{1)}$ Pusat Penelitian dan Pengembangan Hutan \\ ${ }^{2}$ Pusat Penelitian dan Pengembangan Hasil Hutan \\ Jl. Gunung Batu No. 5, Bogor 16610 \\ *e-mail:ujdarmawan@ymail.com
}

\section{ABSTRACT \\ Identification and Control Test of Jabon Leaf Pest by Invitro}

\begin{abstract}
One of problem in jabon (Neolamarckia cadamba [Roxb.] F. Bosser) plantation is defoliator. Identification and control effort are needed to counter this problem. This research was intended to identify pest species attacking plant and do efficacy test of several chemical and biological pesticides against the defoliator. The statistical method of efficacy was Completely Randomized Design (CRD). Two pesticides prophenophos $(0,1 \%)$ and dimethoate $(0,1 \%)$ as chemical based organic pesticides and Bacillus thuringiensis $(0,5 \mathrm{~g} / \mathrm{l})$ as biological pesticide were tested against the defoliator. Data was analyzed using Anova and Tukey test at 95\% confidence level. The result showed that pest was identified as Dysarthria quadricaudata. Chemical and biological pesticides were effective to control the pest.
\end{abstract}

Keywords: Neolamarckia cadamba, Dysarthria quadricaudata, prophenophos, dimethoate, pest.

\begin{abstract}
ABSTRAK
Salah satu persoalan pada hutan tanaman jabon (Neolamarckia cadamba [Roxb.] F. Bosser) adalah serangan hama perusak daun. Pengendalian diperlukan untuk mengatasi persoalan ini. Penelitian bertujuan untuk mengidentifikasi spesies hama dan melakukan efikasi beberapa jenis pestisida kimia dan organik terhadap hama ulat daun jabon ( $N$. cadamba). Metode yang digunakan adalah rancangan acak lengkap. Dua jenis pestisida kimia berbahan profenofos $(0,1 \%)$, dan dimetoat $(0,1 \%)$ serta pestisida organik berbahan dasar Bacillus thuringiensis (0,5 gr/lt) diuji terhadap hama ulat daun. Data dianalisis menggunakan Anova dan uji Tukey $(\mathrm{CI}=95 \%)$. Hasil penelitian menunjukkan bahwa spesies hama yang menyerang tanaman jabon adalah Dysarthria quadricaudata. Jenis pestisida tersebut efektif mengendalikan hama ulat daun jabon.
\end{abstract}

Kata kunci: Neolamarckia cadamba, Dysarthria quadricaudata, profenofos. dimetoat, hama

\section{PENDAHULUAN}

Kebutuhan kayu semakin meningkat sejalan dengan semakin bertambahnya jumlah populasi manusia. Kebutuhan bahan baku industri perkayuan nasional setiap tahun mencapai 72 juta $\mathrm{m}^{3}$. Angka ini merupakan salah satu alasan perlunya untuk membudidayakan tanaman hutan penghasil kayu (Mulyana \& Asmarahman, 2011). Untuk memenuhi kebutuhan tersebut, pemerintah menggalakkan produksi kayu yang dihasilkan melalui hutan rakyat.

Salah satu jenis tanaman hutan rakyat yang sedang diminati masyarakat adalah jabon. Tanaman jabon
(Neolamarckia cadamba) merupakan salah satu jenis tumbuhan asli Indonesia dan beberapa negara tetangga seperti Australia, China, India, Malaysia, Papua Nugini, Filipina dan Vietnam. Dibandingkan dengan jenis pohon lainnya, jabon memiliki keunggulan antara lain: cepat tumbuh, mudah diperbanyak dengan cara generatif (biji) dan vegetatif (stek, sambungan, cangkok dan kultur jaringan), mudah dalam budidaya (penanaman dan pemeliharaan) dan kayunya serbaguna untuk berbagai keperluan seperti papan cor, palet, kotak telur, meubel dan bahan baku industri kayu lapis, moulding dan kertas serta dapat digunakan sebagai bahan obat (Mansur, 2013). 
Salah satu faktor pembatas budidaya tanaman hutan diantaranya adalah kerusakan yang disebabkan kebakaran dan serangan hama dan penyakit (Mulyana \& Asmarahman, 2011). Keberadaan hama dan penyakit tentunya dipengaruhi tiga faktor utama yaitu adanya tanaman inang, keganasan (virulensi) hama dan penyakit serta kondisi lingkungan.

Beberapa jenis hama pada awalnya mungkin tidak diperhitungkan karena belum menunjukkan dampak yang nyata. Namun demikian upaya preventif (pencegahan atau pengendalian) perlu dilakukan untuk menekan resiko kerusakan tanaman dan kerugian yang lebih besar.Di dalam penelitian ini akan dilakukan uji coba teknik pengendalian hama yang effektif.di laboratorium (invitro). Tujuan penelitian ini adalah untuk mengidentifikasi spesies hama dan mengetahui efektivitas dua jenis insektisida kimia dan satu jenis insektisida biologi berbahan aktif Bacillus thuringiensis secara in-vitro terhadap hama perusak daun jabon.

\section{BAHAN DAN METODE}

\section{Bahan dan Alat}

Bahan yang digunakan adalah ulat pemakan daun jabon. Ulat ini dikumpulkan dari tanaman jabon yang terserang di areal arboretum Pusat Penelitian dan Pengembangan Hutan, Bogor, daun jabon segar sebagai pakan ulat, pestisida kimia berbahan aktif profenofos 500 $\mathrm{g} / \mathrm{l}$,dimetoat $400 \mathrm{~g} / \mathrm{l}$ dan pestisida biologi berbahan aktif Bacillus thuringiensis. Peralatan yang digunakan antara lain, cawan petri, kertas saring, kertas tisu dan hand sprayer.

\section{Metode}

\section{Identifikasi Spesies Hama}

Spesimen ulat hidup dikumpulkan secara manual dari tanaman jabon yang terserang. Ulat dipelihara di dalam kurungan serangga dan diberikan pakan berupa daun jabon segar. Pakan baru (segar) diberikan setiap hari sampai ulat menjadi pupa. Serangga dewasa berupa kupu-kupu yang keluar dari kepompong diidentifikasi ciri morfologinya untuk menentukan speciesnya.

\section{Uji Efikasi Pestisida}

Rancangan penelitian yang digunakan adalah rancangan acak lengkap dengan perlakuan berupa pestisida kimia berbahan aktif profenofos $(0,1 \%)$, dimetoat $(0,1 \%)$, dan pestisida biologi berbahan aktif Bacillus thuringiensis $(0,5$ $\mathrm{g} / \mathrm{l}$ ) dan air steril sebagai kontrol dengan tiga ulangan.Teknik aplikasi yang digunakan adalah kontak melalui penyemprotan dengan volume cairan $\pm 0,5$ $\mathrm{ml}$ ke tubuh ulat.Ulat yang telah diperlakukan dimasukkan ke dalam cawan petri yang sebelumnya telah diberikan kertas saring di dalamnya. Kertas saring dimaksudkan untuk mengurangi kelembaban akibat sisa cairan pestisida.

Data berupa mortalitas ulat diperoleh melalui pengamatan setiap 30 menit dan selanjutnya setiap hari.Data tersebut kemudian dianalisis menggunakan sidik ragam dan uji lanjut Tukey $(\mathrm{CI}=95 \%)$. Formula untuk menentukan mortalitas ulat adalah sebagai berikut:

$$
\mathrm{M}(\%)=\frac{\sum \text { ulat mati }}{\sum \text { ulat diamati }} * 100
$$

Keterangan : $\mathrm{M}=$ Mortalitas $(\%)$

\section{HASIL DAN PEMBAHASAN}

\section{Identifikasi Spesies Hama}

Hama ulat pemakan daun jabon diidentifikasi sebagai Dysaethria quadricaudata Walker. Serangga ini tergolong ke dalam famili Uraniidae dan ordo Lepidoptera (Gambar 1). Menurut Borror et al.(1996), Lepidoptera merupakan kelompok serangga hama yang umum dan menimbulkan kerugian secara ekonomis. Dalam siklus hidupnya 
serangga ini mengalami metamorfosis sempurna yang dimulai dengan telur, larva, pupa dan imago. Serangga meletakkan telur di bagian bawah permukaan daun yang telah tua secara berkelompok. Larva (ulat) serangga ini sangat rakus, memintal benang-benang halus yang melingkupi permukaan daun yang dimakannya. Saat larva merasa terganggu, larva menuju benang-benang halus tersebut (Holloway, 1998).

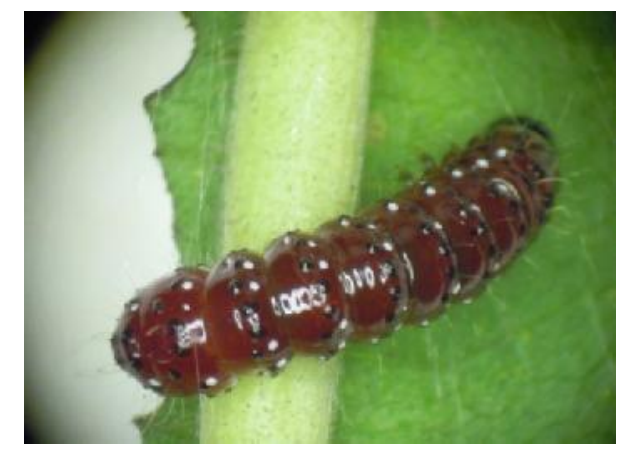

\section{Gambar1. Larva D.quadricaudata}

Hama ini umumnya dijumpai pada daerah dataran rendah, baik pada kawasan hutan, pada areal terdegradasi maupaun kawasan budidaya tanaman. Hama ini dapat dijumpai pada ketinggian $1600 \mathrm{~m}$ dari permukaan laut (Holloway, 1998). Berbagai species tanaman yang tergolong kayu lunak disukai oleh hama ini di dataran rendah (Chey, 1994). Tanaman yang pernah tercatat sebagai inang hama ini adalah tergolong familiRubiaceae. Diantaranya inang tersebut adalah Adina (Browne,
1968),N. cadamba, Nauclea subdita, Mitragyna speciosa(Chunget al., 2012), Cinchona sp. (Sevastopulo, 1941). Sebaran serangga ini meliputi kawasan tropis Indo-Australia yang dapat dijumpai dari Srilangka sampai Taiwan dan Kepulauan Solomon di Pasifik (Holloway, 1998).

\section{Uji Efikasi}

Hasil uji menunjukkan bahwa pestisida kimia maupun pestisida yang berbahan organik yang digunakan dapat mengendalikan hama tersebut. Pada uji statistik antara perlakuan dengan kontrol menunjukkan nilai signifikansi sebesar 0,002 pada 2 hari setelah perlakuan (hsp). Adapun mortalitas serangga uji di antara ketiga perlakuan pestisida tersebut tidak menunjukkan hasil yang berbeda secara nyata pada hari ke dua pengamatan.

Pengaruh pestisida profenofos terhadap mortalitas serangga uji sudah tampak pada 2 jam setelah perlakuan (jsp). Sedangkan pestisida dimetoat dan $B$. thuringiensisbekerja lebih lambat. Gejala peracunan serangga yang teramati adalah adanya penurunan aktivitas baik gerakan maupun aktivitas makan. Beberapa serangga bahkan sudah tidak menunjukkan gejala kehidupan (mati) (Gambar 3). Adapun perlakuan pestisida lainnya tidak menunjukkan respon mortalitas yang berbeda secara nyata terhadap kontrol.

Tabel (Table) 1. Uji beda rata-rata antara perlakuan pada $2 \mathrm{hsp}$

\begin{tabular}{|c|c|c|c|c|c|c|}
\hline \multirow{2}{*}{ Perlakuan } & \multicolumn{6}{|c|}{ Mortalitas ulat (\%) setelah...perlakuan } \\
\hline & 2 jam & & 24 jam & & 48jam & \\
\hline Profenofos & 86.67 & $\mathrm{a}$ & 93.3 & $\mathrm{a}$ & 100 & $\mathrm{a}$ \\
\hline Dimetoat & 13.3 & $\mathrm{~b}$ & 33.33 & $\mathrm{~b}$ & 60 & $\mathrm{a}$ \\
\hline B.thuringiensis & 13.3 & $\mathrm{~b}$ & 40 & $\mathrm{~b}$ & 60 & $\mathrm{a}$ \\
\hline Kontrol & 0 & $\mathrm{~b}$ & 0 & $\mathrm{~b}$ & 0 & B \\
\hline & 0.00 & & 0.002 & & 0.002 & \\
\hline
\end{tabular}




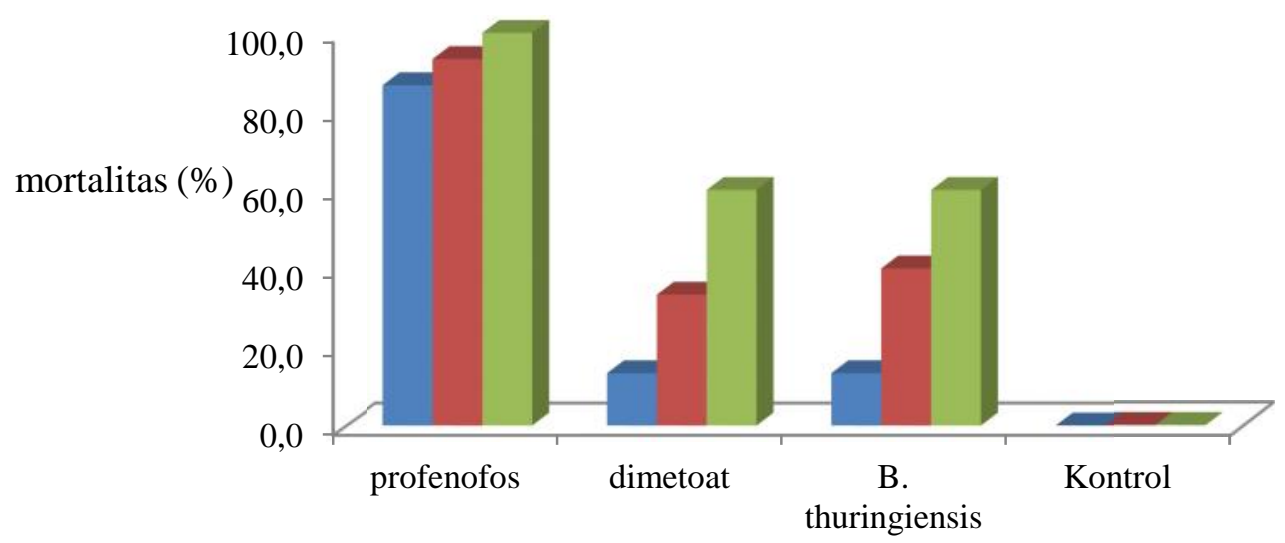

$\square 2$ jam setelah perlakuan $\square 24$ jam setelah perlakuan $\square 48$ jam setelah perlakuan

Gambar 2. Histogram mortalitas serangga uji pada beberapa perlakuan dan pengamatan

Pada 24 jam setelah perlakuan, respon mortalitas serangga uji pada perlakuan pestisida dimetoat dan $B$. thuringiensisjuga belum menunjukkan perbedaan yang nyata terhadap kontrol. Meskipun demikian mortalitas yang terjadi menunjukkan kecenderungan meningkat.Perbedaan ini disebabkan oleh perbedaan jenis dan konsentrasi bahan aktif yang terkandung dalam pestisida tersebut. Pestisida yang digunakan dalam percobaan ini memiliki jenis dan konsentrasi bahan aktif yang berbeda. Jenis bahan aktif profenofos memiliki konsentrasi 500 gr/liter sedangkan bahan aktif dimetoat memiliki konsentrasi sebesar $400 \mathrm{gr} / \mathrm{liter}$.

Meskipun nilai mortalitas sampai pada 24 jam setelah perlakuan belum menunjukkan angka yang berbeda secara nyata antara pestisida dimetoat dan B. thuringiensis terhadap kontrol, gejala peracunan pestisida tersebut terhadap serangga uji sudah terlihat. Hal ini teramati melalui gejala serangga yang aktivitas gerakannya yang menurun (diam). Selain itu aktivitas makan juga terhenti. Hal ini menunjukkan bahwa serangga uji telah terpengaruh pestisida. Adapun pada 48 jam setelah perlakuan mortalitas tiga pestisida tersebut sudah berbeda secara nyata terhadap kontrol.B. thuringiensis adalah senyawa yang bersifat racun lambung dan bekerja relatif lambat (target mati dalam beberapa hari). Hal ini menyebabkan pengaruh mortalitas serangga uji baru terihat setelah 48 jam setelah perlakuan.

Bahan aktif profenofos dan dimetoat merupakan racun yang bekerja secara sistemik melalui lambung maupun bersifat kontak. Dalam hal ini serangga mengalami gangguan biologis karena terpapar secara langsung oleh insektisida yang bersifat kontak maupun gangguan pencernaan melalui toksikasi lambung karena makanan yang telah terkontaminasi.

Profenofos dan dimetoat merupakan bahan kimia aktif yang tergolong dalam kelompok organofosfat. Mekanisme peracunan yang disebabkan oleh organofosfat dipengaruhi oleh struktur kimia, metabolisme organisme target, konsentrasi, modus aplikasi, tingkat dekomposisi, modus masuknya bahan dan sebagainya (Grlić, 1988). Efek racun organofosfat yang lazim diketahui adalah berkaitan dengan sistem saraf sebagai target utama, sedangkan target sekunder di luar itu masih belum jelas.

Mekanisme secara molekuler yang melibatkan bahan organofosfat adalah penghambatan asetilkolin esterase (AChE) (Ecobichon, 1996) pada sistem saraf. Selainorganofosfat, karbamat juga dapat menimbulkan efek serupa. 
Mekanisme penghambatan asetilkolinesterase adalah melalui pengikatan enzim kolinesterase yang berfungsi memecah asetilkolinester (ACh) setelah membawa sinyal-sinyal melalui sistem saraf.

Sinyal yang dikirim melalui sel saraf berupa sinyal listrik dan harus diubah menjadi sinyal kimia. Ketika sinyal yang berupa muatan listrik mencapai ujung sel saraf, hal ini menstimulasi neurotransmitter yaitu pembawa sinyal kimia untuk dilepaskan pada ujung sel saraf.Neurotransmitter ini menyambungkan ke ujung reseptor saraf penerima berikutnya. Sambungan ke reseptor saraf penerima menyebabkan sinyal dirubah kembali menjadi muatan listrik pada sel saraf penerima dan sinyal terus dikirimkan sepanjang sel saraf. Setelah pengiriman pesan melintasi sambungan antara sel saraf, neurotransmitter diurai kembali oleh saraf asalnya dan sel saraf kembali istirahat sampai terdapat sinyal baru yang harus dikirim (Brown, 2006).

Serangga yang telah teracuni oleh penghambat asetilkolinesterase, neurotransmitter (asetilkolin)tidak mampu mengurai ACh sehingga neurotransmitter terus bekerja dan menyebabkan sel saraf "terbakar". Hal ini menyebabkan stimulasi berlebihan terhadap sistem saraf dan menyebabkan kematian (Brown, 2006). Mekanisme keracunan yang disebabkan oleh organofosfat dijelaskan lebih detail oleh Mileson et al., (1998).

Adapun mekanisme pestisida organik $B$. thuringiensisyang berbasis mikroorganisme ini adalah terjadinya lisis sel epitel pada sistem pencernaan. Lisis disebabkan oleh masuknya protein kristal (Cry) dan citolitik (Cyt) ke dalam membran yang membentuk lubang pori. Protein kristal (Cry) dan sitolitik (Cyt) merupakan kelompok protein yang memiliki kemampuan mengendalikan serangga dari berbagai ordo seperti Lepidoptera, Diptera, Coleopteran bahkan Nematoda. (Bravo et al.,2007). Meskipun demikian, B. Thuringiensis cenderung lebih aman terhadap lingkungan biotis (tanaman, vertebrata, invertebrata, manusia) maupun fisik (tanah, air) (Joung \& Côté. 2000). Racun cry berinteraksi dengan reseptor khusus yang terdapat pada permukaan sel inang dan teraktivasi oleh ikatan reseptor dan protease inang yang menyebabkan terbentuknya struktur pori oligomerik (Bravo et al.,2007). Mekanisme secara lebih rinci dijelaskan oleh Roh et al., (2007).

\section{KESIMPULAN}

Jenis hama yang menyerang daun jabon diidentifikasi sebagai Dysaethria quadricaudataWalker yang tergolong dalam famili Uraniidae dan ordo Lepidoptera. Serangga ini berperan sebagai hama pada fase larva (ulat). Tanaman inangnya umumnya adalah dari kelompok tanaman rubiaceae. Insektisida organofosfatdengan konsentrasi setangah dari dosis anjuran sudah cukup efektif mengendalikan hama ini. Mekanisme bahan kimia berperan sebagai racun kontak dan sistemik melalui penghambatan asetilkolinesterase (AChE) pada system saraf. Sedangkan pestisida berbahan aktif $B$. thuringiensis meracuni serangga yang utamanya adalah melalui terjadinya lisis sel epitel pada sistem pencernaan. Meskipun pengaruh pestisida yang berbahan aktif $B$. thuringiensis cenderung lambat, namun hasilnya nyata dapat mengendalikan hama $D$. quadricaudatadan lebih ramah terhadap lingkungan. Hasil penelitian ini menyimpulkan bahwa insektisida yang berbahan aktif profenofos dan dimetoat efektif mengendalikan hama ini. Namun demikian penggunaan pestisida berbahan aktif $B$. thuringiensis lebih disarankan karena lebih ramah terhadap lingkungan. 


\section{DAFTAR PUSTAKA}

Borror, D.J., C.A. Triplehorn, N.F. Johnson. 1996. An Introduction to the Study of Insects Sixth Edition. Saundees College Publishing. Rinehart and Winston. Inc.

Bravo, A., S.S. Gill., M. Soberón. 2007. Mode of action of Bacillus thuringiensis Cry and Cyt toxins and their potential for insect control. Toxicon. 49(4): 423-435.

Brown, A.E. 2006. Mode of Action of Structural Pest Control Chemicals. Pesticide Informa-tion Leaflet No. 41. Informa-tion, Department of entomo-logy, Maryland cooperative extention, University of Maryland. USA.

Browne, F.G. 1968. Pests and diseases of forest plantation trees: an annotated list of the principal species occurring in the British Commonwealth.

Oxford Clarendon. UK.

Chung, A.Y.C., K. Kimjus., M. Ajik. 2012. Infestation of Dysaethria quadricaudata caterpillars (Lepidoptera:Uraniidae:Epiplemin ae) and its control measure, with reference to evaluation on different insecticide effectiveness. Sep. Bul. 15 \& 16(1): 17-25.

Dubois, N.R., F.B. Lewis. 1981. What Is Bacillus thuringiensis .J. Arbori. 7(9):233-240.

Ecobichon, D. J. 1996. Toxic effects of pesticides. In Casarett \&. Doull's Toxicology (C. D. Klaassen, M. 0. Amdur, and $\mathrm{J}$ Doull, Eds.). Mc.Graw-Hill, New York.

Grlić, L. 1988. Mali kemijski leksikon Napried, Zagrebdalam Stoytcheva, M (ed). 2011. Pesticides - The Impacts of
Pesticides Exposure. InTech, Rijeka, Croatia.

Holloway, J.D. 1998. The Moths of Borneo, Part 8; Families Castniidae, Callidulidae, Drepanidae And Uraniidae. http://www.mothsofborneo.com/ diakses 3 juni 2013.

Joung, K.B., J.C. Côté. 2000. A review of the environmental impactsof the microbial insec-ticide Bacillus thuringiensis. Technical Bulletin No. 29. Horticultural Research and Development Centre. Agriculture and Agri-Food. Canada.

Mansur, I. 2013. Prospek pengembangan jabon untuk mendu-kung pengembangan hutan ta-naman. Makalah disampaikan dalam Seminar dan Pameran hasil-hasil Penelitian dengan Tema "Prospek Pengembangan Hutan Tanaman (Rakyat), Konservasi, dan Rehabilitasi Hutan". Manado, 23 Oktober 2013.

Mileson, B.E., J.E. Chambers., W.L. Chen., W. Dettbarn., M. Enrich., A.T. Eldefrawi., D.W. Gaylor., K. Hamernik., E. Hodgson., A.G. Karczmar., S.Padilla., C. N. Pope., R.J. Richardson., D.R. Saunders., L.P. Sheets., L. G. Sultatos., K.B. Wallace. 1998. Common mechanism of toxicity: a case study of organophosphorus pesticides.ToxicologicalSciences, 41: 8-20.

Mulyana, D. dan C. Asmarahman. 2011. 7 Jenis Kayu Penghasil Rupiah. Penerbit PT Agro-media Pustaka. Jakarta.

Orwa C., A. Mutua.,R. Kindt., R. Jamnadass., S. Anthony. 2009 Agroforestree Databasea tree reference and selection guide version 4.0. http://www. worldagroforestry.org/treedb/AFT 
PDFS/Anthocephalus_cadamba.P DF. (diakses 26 juni 2015)

Roh, JY., J.Y. Choi., M.S. Li., B.R. Jin., Y.H. Je. 2007. Bacillus thuringiensis as a specific, safe, and effective tool for insect pest control. Journal of Micro-biology and Biotechnology, 17(4): 547559 .

Sevastopulo, D.G.1941. On the food plants of Indian Bombyces (Heterocera). Journal of the Bombay Natural History Society 41:817-827. 